\title{
Perception of Farmers towards Field Trip (Shivar pheri) of Dr. PDKV Akola
}

\author{
P.B. Chikte, K.T. Lahariya, P.P Chavan and M.P. Shinde*
}

Director of Extension Education, Dr. Panjabrao Deshmukh Krishi Vidyapeeth, Akola, India

*Corresponding author

\section{A B S T R A C T}

Keywords

Shivar pheri,

Interface programme, Field visit

Article Info

Accepted:

12 February 2019

Available Online:

10 March 2019
On the eve of University foundation day i.e. $20^{\text {th }}$ October, every year three days field trip (Shivar Pheri) is organized at mega level by Dr. Panjabrao Deshmukh Krishi Vidyapeeth, Akola. During these 3 days all the scientists remain present on their respective field, to disseminate the information about agriculture and to deliver the information about university developed technology. A dialogue between farmers and scientist helps to nullify the barricades in adoption of innovative technologies because individual or face to face method are probably most used extension method in whole university. After this field visit at the end of day, there is an interface programme between scientist and farmers, where farmers asked the querries about the field visit or problems faced by them in their farm. Likewise, taking in consideration the huge response of farmers from 11 district of Vidarbha, it is decided to make the analysis of the field trip, so that it would be feasible to increase the effectiveness of the programme.

\section{Introduction}

The field trip is one of the many instructional techniques that classroom teachers have used in their instructional programme. The exact origin of the field trip is not known (Mccaslin, 1970). According to (Kinder, 1950) Herodotus and Xenophan, Greek peripatetic teachers, who traveled abroad to gain their knowledge of peoples and land, were among the earliest field trip.

During field trip the extension agents meet the farmers, giving the farmers both information and advice. The atmosphere of meeting is usually informal and relaxed, and the farmers are able to benefit from agent individual attention. Learning is very much an individual process and although group methods enables the agent to reach a greater number of farmers.

Field trip enables to give specific advice or information to the farmers built up knowledge of the area, and kind of problems which farmers face, permit him to explain a new recommended practice or follow up and observe results to date as well as arouse general interest among the farmers and stimulate their involvement in extension activities. Good field trip provides participants with firsthand experience related to topic or concept being discussed in programme. They 
provide unique opportunities for learning that are not available within four walls of classroom (Anonymous, 2017) considering all benefits of field trip and response of farmers, it was thought appropriate to conduct study on farmers perception towards field trip (Shivarpheri) inspired to conduct study.

\section{Materials and Methods}

The data was gathered by questionnaire collected from randomly selected samples from 107 farmers for post trip analysis organized by Dr Panjabrao Deshmukh Krishi Vidyapeeth, Akola during 2016 for further analysis according to different objectives.

\section{Results and Discussion}

\section{Source of information about field trip}

As per the data given in Table 1, illustrated that highest number of farmers (43.93 per cent) knew information regarding organization of field trip from news paper followed by 22.43 per cent farmers know about organization of field trip by the university (toll free helpline of university and SMS service).While very meager percentage of farmers i.e. 8.41 and 3.74 per cent farmers get information by krishi doot, friends and others, respectively.

\section{Mode of expenses for participation in field trip}

Amongst the farmers, who participated in field trip, analysis done for mode of expenses over travel fair for participation in field trip.

The data given in Table 2 reveals that major proportion of farmers i.e. 86.92 per cent participated by their own expenses, while only 13.08 per cent farmers participated by the expenses of various agencies of government or NGO's.

\section{Frequency of visit to field trip organized by University}

As mentioned earlier, field visit is organized every year by the university on the eve of university foundation day i.e. $20^{\text {th }}$ October. The data illustrated in Table 3 indicated that 52.34 per cent farmers participated for the first time in field trip, while 17.76 per cent farmers participated twice followed by 8.41, 7.48, and 6.54 per cent farmers participated thrice, four, five and more than five times respectively. Repeated participation might be due to good exposure of information and farmers wants to upgrade their knowledge in arena of agriculture.

\section{Intention of visit to field trip}

The data given in Table 4 revealed that, there are various intensions of participants, who attended field visit such as to acquire knowledge about new crop varieties /technologies were highest (43.93 per cent), followed by 50 farmers, who visited university field visit to acquire knowledge about agro based subsidiary occupation. While very meager proportion of farmers such as 7.48 and 6.44 per cent visited field trip to see university and visit along with friends, respectively.

Information perceived to be relevant by the farmers after visiting various centres

As per results obtained by questionnaire which are explained in Table 5, illustrated that highest percentage of farmers perceived relevant information from Senior Research Scientist(SRS) cotton, SRS oilseed, SRS puses, SRS sorghum and horticulture department were 64.49,53.27,47.66,45.79 and 42.06 per cent, respectively. It is too obvious because cropping pattern of Vidarbha mainly cotton +pulses, cotton +black gram, cotton +green gram, cotton +pigeonpea in oilseed crop groundnut, safflower and horticultural 
crops like lemon, mandarins guava and custard apple. Hence the highest percentage of farmers perceived relevant information in respect of their crop husbandry. Followed by departments were animal husbandry and dairy science, dry land research project, farm implements i.e. $38.32,34.58$ and 31.78 per cent, respectively. Because devoid of cropping pattern all most all farmers have subsidiary enterprise with farming is dairy, which is followed by dry land farming pattern considering the constraints of irrigation on large area of Vidarbha, which is followed by farm equipments because utility of farm equipment is need of the day due to labour problem. While meager per cent of relevant information obtained from AICRP on citrus fruit, exhibition of Dr PDSK and watershed were $19.63,17.76$ and 10.28 per cent, respectively as perceived by farmers.

\section{Change in knowledge after participation in field trip}

The data given in Table 6 indicate that, the change in knowledge of farmers after participation in field trip. Among the participant farmers experienced for change in knowledge due to participation in field trip i.e. 41.12 per cent farmers reported that their knowledge is upgrade by 61 to 80 per cent. While 30.84 and 19.63 per cent of farmers committed that they experienced the change in knowledge due to participation in field trip of universities above 80 per cent and 41-60 per cent respectively. While some farmers noted 6.54 and 1.87 percent change in knowledge of 21 to 40 per cent and up to 20 per cent of farmers, respectively.

\section{Meeting of objectives after visit to field trip}

The data explored in Table 7 reveals that to what extent farmers were satisfied to meet objectives after visit to field trip. In all, highest percentage of farmers experienced the objective of visit to field trip is completely met (79.44 per cent) due to participation in field trip, while 15.89 per cent farmers felt that the objective were met to some extent and very few farmers quoted that the visit of university trip is not fulfilled (4.67 per cent).

\section{Perception of farmers towards benefit of knowledge gain in own farming}

The data given in Table 8 indicated that percentage adoption of university developed varieties /technologies amongst the farmers, who participated in field trip of university. The conclusion of results, indicates that 60.75 per cent farmers adopted university developed technologies. While 39.25 per cent farmers are not using, technologies of university.

\section{Adoption of University developed varieties / technologies}

The data explored in Table 9, reveals that the adoption of university developed technologies by the farmers. With respect to cotton, results show that lesser number of farmers adopted conventional cotton varieties such as 12.84 , 10.7 and 10.7 per cent, respectively, who cultivated AKH-081, AKA -5 and AKA-7. It is obvious because now days farmers are growing genetically modified crop (Bt cotton) rather than arboreum varieties of cotton. This results justified by the results of (Sadashivappa, 2017), who reported bt cotton adoption by the farmers over conventional cotton hybrids to save expense over pest control and to obtain higher yield.

In respect of pulses results obtained were 20.33, 25.68, 27.82 per cent farmers adopt university varieties, for cultivation of green gram, black gram, and pigeon pea and gram, respectively. And promising results obtained due high yielding performance of pulses varieties Adoption of university varieties for cultivation of sorghum, results indicate that 
7.49, 10.7 and 17.12 per cent farmers cultivated varieties $\mathrm{CSH}-30$, SPH 333 and $\mathrm{SPH}-1635$. The decline in adoption of sorghum varieties might be due to decreased interest in growing sorghum. Because longer duration of crop does not facilitate to take crop during Rabi. This decreases cropping intensity and income ultimately. Which increased the popularity some other cropping pattern?

Adoption of university varieties in respect of groundnut in promising, because the popularity of TAG -24 variety of groundnut 73.83 per cent farmers adopted the variety. While 28.89 per cent farmers adopted AK 303 variety of ground nut.

In respect of horticulture crops results indicate that the 22.47 per cent farmers grow onion AKOLA Safed and 9.63 per cent farmers grow bean variety Dipali.

\section{Farmer to farmer extension about University developed technologies}

The results given in Table 10 indicate that farmers to farmer extension about university developed technologies is done by participating farmers in the field i.e. parallel spread of technology. The inference of result entails 32.71 per cent farmers done extension of university developed technologies within 11 to 15 farmers. While 22.43 per cent farmers disseminate the information about university developed technologies with more than 15 farmers.

Table.1 Source of information about field trip $(n=107)$

\begin{tabular}{|c|l|c|c|}
\hline Sr. No & Source of Information & Number & Percentage \\
\hline $\mathbf{1}$ & University & 23 & 21.50 \\
\hline $\mathbf{2}$ & State Depatment of Agriculture & 24 & 22.43 \\
\hline $\mathbf{3}$ & News paper & 47 & 43.93 \\
\hline $\mathbf{4}$ & Krishi Doots & 09 & 08.41 \\
\hline $\mathbf{5}$ & Friends \& others & 04 & 03.74 \\
\hline & & $\mathbf{1 0 7}$ & $\mathbf{1 0 0}$ \\
\hline
\end{tabular}

Table.2 Mode of expenses for participation in field trip

\begin{tabular}{|c|c|c|c|}
\hline Sr. No & Mode of Expenses & Number & Percentage \\
\hline 1 & By own expenses & 93 & 86.92 \\
\hline 2 & By Govt. Expenses & 14 & 13.08 \\
\hline & Total & 107 & 100 \\
\hline
\end{tabular}

Table.3 Frequency of visit to field trip organized by University

\begin{tabular}{|c|c|c|c|}
\hline Sr. No & Frequency of visit & Number & Percentage \\
\hline 1 & First Time & 56 & 52.34 \\
\hline 2 & Two times & 19 & 17.76 \\
\hline 3 & Three times & 09 & 8.41 \\
\hline 4 & Four times & 08 & 7.48 \\
\hline 5 & Five Times & 08 & 7.48 \\
\hline \multirow[t]{2}{*}{6} & More than Five Times & 07 & 6.54 \\
\hline & Total & 107 & 100 \\
\hline
\end{tabular}


Table.4 Intention of visit to field trip

\begin{tabular}{|c|l|c|c|}
\hline Sr. No & Intention of Visit & Number & Percentage \\
\hline $\mathbf{1}$ & $\begin{array}{l}\text { To acquire knowledge about new crop varieties / } \\
\text { technologies }\end{array}$ & 47 & 43.93 \\
\hline $\mathbf{2}$ & $\begin{array}{l}\text { To acquire knowledge about agro-based subsidiary } \\
\text { occupation }\end{array}$ & 50 & 46.73 \\
\hline $\mathbf{3}$ & To see the University & 07 & 6.54 \\
\hline $\mathbf{4}$ & To visit along with friends & 03 & 2.80 \\
\hline & & $\mathbf{1 0 7}$ & $\mathbf{1 0 0}$ \\
\hline
\end{tabular}

Table.5 Information perceived to be relevant by the farmers after visiting various centres

\begin{tabular}{|c|l|c|c|}
\hline Sr. No. & \multicolumn{1}{|c|}{ Name of Center } & Frequency & Percentage* \\
\hline $\mathbf{1 .}$ & Senior Research Scientist, Cotton & 69 & 64.49 \\
\hline $\mathbf{2 .}$ & Senior Research Scientist, Oilseed & 57 & 53.27 \\
\hline $\mathbf{3 .}$ & Senior Research Scientist, Pulses & 51 & 47.66 \\
\hline $\mathbf{4 .}$ & Senior Research Scientist, Sorghum & 49 & 45.79 \\
\hline $\mathbf{5 .}$ & Horticulture Department & 45 & 42.06 \\
\hline $\mathbf{6 .}$ & AHDS (Animal Exhibition) & 41 & 38.32 \\
\hline $\mathbf{7 .}$ & Dry land Research Project & 37 & 34.58 \\
\hline $\mathbf{8 .}$ & Farm Implements Exhibition & 34 & 31.78 \\
\hline $\mathbf{9 .}$ & Nagarjuna Medicinal Plants Garden & 27 & 25.23 \\
\hline $\mathbf{1 0 .}$ & AICRP on citrus fruit & 21 & 19.63 \\
\hline $\mathbf{1 1 .}$ & Exhibition Dr. PDSK & 19 & 17.76 \\
\hline $\mathbf{1 2 .}$ & Water Shed & 11 & 10.28 \\
\hline
\end{tabular}

* Sum of percentage is more than 100 due to multiple responses

Table.6 Change in Knowledge after participation in field trip

\begin{tabular}{|c|c|c|c|}
\hline Sr. No & Change in Knowledge & Number & Percentage \\
\hline 1 & Up to $20 \%$ & 02 & 1.87 \\
\hline 2 & $21 \%$ to $40 \%$ & 07 & 6.54 \\
\hline 3 & $41 \%$ to $60 \%$ & 33 & 30.84 \\
\hline 4 & $61 \%$ to $80 \%$ & 44 & 41.12 \\
\hline \multirow[t]{2}{*}{5} & Above $80 \%$ & 21 & 19.63 \\
\hline & Total & 107 & 100 \\
\hline
\end{tabular}

Table.7 Meeting of objective after visit to field trip

\begin{tabular}{|c|c|c|c|}
\hline Sr. No & Meeting of objective & Number & Percentage \\
\hline 1 & Completely met & 85 & 79.44 \\
\hline 2 & Met to some extent & 17 & 15.89 \\
\hline 3 & Not met & 05 & 4.67 \\
\hline & Total & 107 & 100 \\
\hline
\end{tabular}


Table.8 Perception of farmers towards benefit of knowledge gain in own farming

\begin{tabular}{|c|l|c|c|c|}
\hline Sr. No & \multicolumn{2}{|c|}{ Benefit of Knowledge } & Number & Percentage \\
\hline $\mathbf{1}$ & Yes & & 103 & 96.26 \\
\hline $\mathbf{2}$ & No & Total & 04 & 3.74 \\
\hline & & $\mathbf{1 0 7}$ & $\mathbf{1 0 0}$ \\
\hline
\end{tabular}

Table.9 Adoption of University developed varieties / technologies

\begin{tabular}{|c|l|c|c|c|}
\hline Sr. No & & Adoption & Number & Percentage \\
\hline $\mathbf{1}$ & Yes & & 65 & 60.75 \\
\hline $\mathbf{2}$ & No & & 42 & 39.25 \\
\hline & & Total & $\mathbf{1 0 7}$ & $\mathbf{1 0 0}$ \\
\hline
\end{tabular}

Table.10 Farmer to farmer extension about University developed technologies

\begin{tabular}{|c|l|c|c|}
\hline Sr. No & Farmer to farmer extension & Number & Percentage \\
\hline $\mathbf{1}$ & Up to 5 farmers & 19 & 17.76 \\
\hline $\mathbf{2}$ & 6 to 10 farmers & 29 & 27.10 \\
\hline $\mathbf{3}$ & 11 to 15 farmers & 35 & 32.71 \\
\hline $\mathbf{4}$ & Above 15 farmers & 24 & 22.43 \\
\hline & & $\mathbf{1 0 7}$ & $\mathbf{1 0 0}$ \\
\hline
\end{tabular}

Table.11 Adoption of University developed technologies by the farmers

\begin{tabular}{|c|l|c|c|}
\hline Sr. No. & \multicolumn{1}{|c|}{ Crop variety / Technology } & Frequency & Percentage* $^{* \mid}$ \\
\hline $\mathbf{1 .}$ & Cotton & 12 & 12.84 \\
\hline $\mathbf{1 . 1}$ & AKH - 081 & 10 & 10.7 \\
\hline $\mathbf{1 . 2}$ & AKA - 5 & 10 & 10.7 \\
\hline $\mathbf{1 . 3}$ & AKA - 7 & 09 & \\
\hline $\mathbf{1 . 4}$ & AKA - 8 & 19 & 20.33 \\
\hline $\mathbf{2 .}$ & Pulses & 24 & 25.68 \\
\hline $\mathbf{2 . 1}$ & Mung (Green Gold) & 26 & 27.82 \\
\hline $\mathbf{2 . 2}$ & Udid (TAU - 1) & 77 & $\mathbf{8 2 . 3 9}$ \\
\hline $\mathbf{2 . 3}$ & Tur (TARA) & 07 & \\
\hline $\mathbf{2 . 4}$ & Gram (Jaki - 9218) & 10 & 10.7 \\
\hline $\mathbf{3 .}$ & Sorghum & 16 & 17.12 \\
\hline $\mathbf{3 . 1}$ & CHS - 30 & & \\
\hline $\mathbf{3 . 2}$ & SPH - 388 & 69 & $\mathbf{7 3 . 8 3}$ \\
\hline $\mathbf{3 . 3}$ & SPH -1635 & 27 & 28.89 \\
\hline $\mathbf{4 .}$ & Oil seeds & & \\
\hline $\mathbf{4 . 1}$ & Groundnut (TAG - 24) & 21 & 22.47 \\
\hline $\mathbf{4 . 2}$ & Groundnut (AK - 303) & 09 & 9.63 \\
\hline $\mathbf{5 .}$ & Horticultural Crops & & \\
\hline $\mathbf{5 . 1}$ & Onion Safed & & \\
\hline $\mathbf{5 . 2}$ & Bean Dipali & & \\
\hline
\end{tabular}

* Sum of percentage is more than 100 due to multiple responses 
Table.12 Benefit due to adoption of university developed technologies

\begin{tabular}{|c|l|c|c|}
\hline Sr. No. & \multicolumn{1}{|c|}{ Crop variety / Technology } & Frequency & Percentage* \\
\hline $\mathbf{1 .}$ & $\begin{array}{l}\text { Increase in crop yield due to adoption on soil water and } \\
\text { conservation practices }\end{array}$ & 27 & 28.89 \\
\hline $\mathbf{2 .}$ & Time and money saving due to farm implements & 24 & 25.68 \\
\hline $\mathbf{3 .}$ & Gain knowledge to identify insect pest and their control & 20 & 21.4 \\
\hline $\mathbf{4 .}$ & Increase in yield of cotton crop & 17 & 18.19 \\
\hline $\mathbf{5 .}$ & Able to control wilting in tur crop & 14 & 14.98 \\
\hline $\mathbf{6 .}$ & $\begin{array}{l}\text { Increase in milk production, saving of feed and fodder } \\
\text { due to silage making and azola feeding to milch animals }\end{array}$ & 11 & 11.77 \\
\hline $\mathbf{7 .}$ & $\begin{array}{l}\text { Able to take crop in summer due to adoption of } \\
\text { University developed technologies }\end{array}$ & 09 & 9.63 \\
\hline $\mathbf{8 .}$ & Harvested Soybean 15 q/acre & 06 & 6.42 \\
\hline $\mathbf{9 .}$ & $\begin{array}{l}\text { Increase in yield of crops due to trainings received from } \\
\text { University }\end{array}$ & 04 & 4.28 \\
\hline
\end{tabular}

* Sum of percentage is more than 100 due to multiple responses

Table.13 Opinion toward organization of field trip-2016

\begin{tabular}{|c|l|c|c|c|}
\hline Sr. No & Opinion toward organization & Number & Percentage \\
\hline $\mathbf{1}$ & Very good & 77 & 71.96 \\
\hline $\mathbf{2}$ & Good & 24 & 22.43 \\
\hline $\mathbf{3}$ & Fair & Total & $\mathbf{1 0 7}$ & 5.61 \\
\hline & & & $\mathbf{1 0 0}$ \\
\hline
\end{tabular}

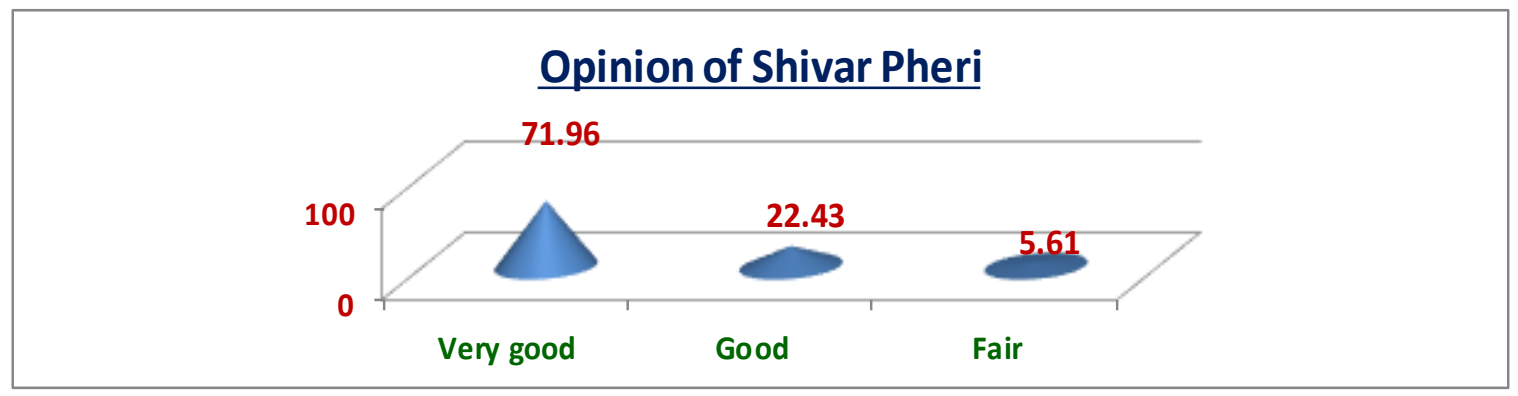

Meager per cent of farmers 27.1 per cent shared technologies of university within 6 to 10 farmers and 17.76 per cent sharing is done up to 5 farmers (Table 11).

\section{Benefit due to adoption of University developed technologies}

The results obtained from Table 12, indicates benefit due to adoption of university developed technologies. Such as increase in crop reported (28.89 per cent) due to farmers adoption of soil water and conservation practices, followed by saving in time and money due to use of farm implements, reported 25.68 per cent farmers. Gain in knowledge to identify insect pest and their control is noticed by 21.4 per cent followed by increase in yield of cotton (18.19 per cent), which is followed by control in wilt of tur 
crop (14.98 per cent) and increase in milk production, saving of feed fodder due to silage making and azola feeding to milch animals (11.77 per cent). While some farmers experienced benefit due to adoption of university developed technologies, they able to take crop in summer were 9.63 per cent as well as some farmers benefitted by university developed technologies, which made them possible to harvest soybean crop 15 qui/ha were 6.42 per cent. While 4.28 per cent farmers reported increase in yield of crop due to training received from university.

\section{Benefit due to adoption of University Developed Technologies}

The data given in Table 13 indicate that opinion of farmers about organization of field trip. The higher proportion of farmers 71.96 per cent notified very good opinion toward organization of field trip. Followed by 22.43 per cent realized that organization of field trip was good. While only 5.61 per cent farmers coated fair remark for organization field trip.

\section{References}

Anonymous 2017. FAO Corporate docummentry repository www. Fao.org/dox rep/t0060 e/ T0060E07.htm

Kinder James (1950). Audio Visual material \& techniques. New York, American Book Company (1950)

MC Caslin, Norval (1970). Experimental evaluation of field trips on instruction in vocational agriculture, retrospective thesis \& dissertation, Iowa State University paper 4343.

Prakash Sadashivaappa (2017). Bt Cotton in India development of benefits \& role of government seed price interventions. J. of Agribiotechnology Management \& Economics Vol.12 (2) article - 3. x

\section{How to cite this article:}

Chikte, P.B., K.T. Lahariya, P.P Chavan and Shinde, M.P. 2019. Perception of Farmers towards Field Trip (Shivar pheri) of Dr. PDKV Akola. Int.J.Curr.Microbiol.App.Sci. 8(03): 1326-1333. doi: https://doi.org/10.20546/ijcmas.2019.803.157 